\title{
Retainer Kaitan Presisi Ekstrakorona Pada Kasus Kennedy Klas I Rahang Bawah
}

\author{
Fajar Kartika, Endang Wahyuningtyas, Erwan Sugiatno, dan Heriyanti AK \\ Program Studi Prostodonsi, PPDGS, Fakultas Kedokteran Gigi, Universitas Gadjah Mada \\ JI Denta no 1 Sekip Utara Yogyakarta, Indonesia; e-mail: fajarkartika86@yahoo.co.id
}

\begin{abstract}
INTISARI
Rehabilitasi gigi yang hilang dengan gigi tiruan sebagian lepasan adalah untuk memperbaiki fungsi pengunyahan, estetika, fungsi bicara, mempertahankan gigi dan jaringan yang masih ada, menjaga stabilitas oklusi, serta mengembalikan kenyamanan pasien. Penggunaan gigi tiruan dengan retainer kaitan presisi menjadi pilihan karena dapat meningkatkan kenyamanan pasien dalam memakai gigi tiruan. Kaitan presisi adalah suatu perangkat interlocking kecil untuk menghubungkan gigi tiruan dengan gigi pegangan yang dapat memberikan manfaat biomekanik dan estetis. Laporan kasus ini bertujuan memberikan informasi tentang gigi tiruan dengan kaitan presisi ekstrakorona pada kasus Kennedy klas I rahang bawah untuk meningkatkan kenyamanan pasien dalam memakai gigi tiruan. Pasien perempuan usia 56 tahun datang ke klinik Prostodonsia RSGM Prof. Soedomo ingin dibuatkan gigi tiruan baru. Pasien sebelumnya telah mengunakan gigi tiruan kerangka logam pada rahang atas (RA) dan rahang bawah (RB), namun merasa kurang percaya diri dan tidak nyaman dengan gigi tiruannya. Pasien ingin dibuatkan gigi tiruan yang tidak menggunakan plat yang melintang pada rahang bawahnya. Pembuatan gigi tiruan sebagian lepasan rahang bawah dengan retainer kaitan presisi ekstrakorona. Tatalaksana perawatan 1)Pencetakan rahang untuk model diagnostik, 2)Preparasi gigi penyangga, 3) Pencetakan model kerja dan pembuatan mahkota sementara, 4)Try in coping kaitan presisi RB, 5)Pencatatan hubungan RA-RB, 6)Prosesing lab, 7)Insersi, 8)Kontrol. Gigi tiruan sebagian lepasan rahang bawah dengan retainer kaitan presisi ekstrakorona dapat digunakan pada kasus Kennedy klas I untuk meningkatkan kenyamanan pasien. Maj Ked Gi. Juni 2014; 21(1):66-71
\end{abstract}

Kata kunci: Gigi tiruan sebagian rahang bawah, kaitan presisi ekstrakorona, kenyamanan pasien.

\begin{abstract}
Mandibular Extracoronal Precission Attachment Retainer On Mandibular Kennedy Class I Cases. Rehabillitation of missing teeth with removable partial denture is to restore mastication, aesthetic, speech functional, preserve the teeth and remaining tissue, maintaining the occlusal stabilities, and to restore patient comfort of using removable partial denture. Removable partial denture with precision attachment become an option because it can increase patient comfort when using denture. Precision attachment is a small interlocking device to connect prosthesis and abutments that offer a variety of solutions to the challenge of balance between biomechanical benefit and aesthetic appeal. This case report aims to provide more option of removable partial denture with extracoronal precision attachment on mandibular Kennedy class I cases to enhance patient comfortability when using dental prosthesis. A 56 years old female patient came to the Prosthodontics clinic of RSGM Prof. Soedomo want to made a new denture. The patient had previously been using metal frame denture on the upper jaw and mandible, but feel less confident and uncomfortable with the denture. Patient want to be made a new denture that do not use transverse plate on the lower jaw. Removable partial denture with extracorona precision attachment for the lower jaw was suggested. The case management were: 1) Jaw impression for diagnostic model, 2) Abutment preparation, 3) Working cast impression and temporary crown make, 4) Lower jaw precision attachment try in coping, 5) Upper and lower jaw relation recording, 6) Lab. Processing, 7) Insertion, 8) Control. Conclusion: Removable partial denture for lower jaw with extracorona precision attachment can be used to improved patients comfort.
\end{abstract}

Maj Ked Gi. Juni 2014; 21(1):66-71

Key words: Mandibular partial denture, extracorona precision attachment, patient comfort.

\section{PENDAHULUAN}

Gigi yang rusak adalah keadaan terdapat kerusakan sebagian atau kehilangan satu atau lebih elemen. Kerusakan gigi sangat bervariasi dari yang paling sederhana hingga kerusakan yang luas. ${ }^{1}$ Kerusakan gigi harus direhabilitasi dengan pembuatan gigi tiruan untuk mengembalikan kesehatan dan fungsi gigi dan mukosa. Fungsi pembuatan gigi tiruan sebagian lepasan adalah untuk memperbaiki fungsi pengunyahan, estetika, fungsi bicara, mempertahankan gigi yang masih ada, menjaga stabilitas oklusi, serta mengembalikan kenyamanan pasien. ${ }^{2}$ 
Hal yang harus diperhatikan dalam pembuatan gigi tiruan sebagian lepasan adalah retensi dan stabilisasi gigi tiruan ${ }^{3}$.Untuk menghasilkan retensi gigi tiruan, cangkolan konvensional merupakan alat yang dipakai karena proses pembuatannya mudah. Besarnya retensi yang dihasilkan tergantung dari dalamnya daerah gerong yang ditempati lengan retentive, modulus elastisitas logam, penampang, panjang dan arah datang serta letak lengan cangkolan terhadap garis fulkrum. Dengan adanya retensi maka gigi tiruan akan mencegah gerakan yang ditimbulkan. ${ }^{1,2,3}$

Dengan perkembangan ilmu pengetahuan dan teknologi yang semakin pesat di bidang kedokteran gigi, cangkolan konvensional yang digunakan sebagai retensi gigi tiruan dapat diganti dengan penggunaan kaitan presisi untuk menghasilkan retensi yang lebih baik. ${ }^{1}$ Kaitan presisi adalah suatu perangkat interlocking kecil untuk menghubungkan gigi tiruan dengan gigi pegangan yang dapat memberikan manfaat biomekanik dan estetis. ${ }^{4}$ Dengan pemakaian kaitan presisi akan diperoleh dukungan, retensi, stabilisasi gigi tiruan sebagian lepasan dengan optimal, ${ }^{1}$ sehingga akan memberikan rasa nyaman dan estetis yang lebih baik bagi pasien saat menggunakan gigi tiruan. Adapun tujuan dari laporan kasus ini adalah untuk memberikan informasi tentang gigi tiruan dengan kaitan presisi ekstrakorona untuk peningkatan estetis dan kenyamanan pasien. ${ }^{1}$ Laporan kasus ini telah mendapat persetujuan dari pasien untuk dipublikasikan demi kepentingan ilmu pengetahuan.

\section{METODE}

Pasien perempuan usia 56 tahun datang ke klinik Prostodonsia RSGM Prof. Soedomo FKG UGM karena ingin dibuatkan gigi tiruan baru. Pasien sebelumnya telah mengunakan gigi tiruan kerangka logam pada rahang atas (RA) dan rahang bawah (RB), namun merasa kurang percaya diri dan tidak nyaman dengan gigi tiruannya. Pasien merasa tidak nyaman dan kurang percaya diri saat menggunakan gigi tiruan kerangka logam rahang bawahnya karena pasien merasa ada plat yang melintang di depan lidah dan dirasa terlalu tebal, sehingga pasien ingin dibuatkan gigi tiruan yang tidak menggunakan plat yang melintang pada rahang bawahnya.

Keadaan umum pasien baik dan tidak memiliki riwayat penyakit sistemik. Pada pemeriksaan klinis ekstra oral tidak ditemukan kelainan. Pada pemeriksaan klinis intraoral, Pasien kehilangan gigi 36,37 , dan 47 pada RB yang merupakan klasifikasi Applegate-Kennedy klas I (Gambar 1). Kebersihan rongga mulut pasien baik, tidak ditemukan adanya kalkulus pada gigi yang masih ada. Tidak ditemukan adanya kegoyangan gigi pada gigi yang masih ada. Pada pemeriksaan radiografi terdapat gigi 46 pasca perawatan endodontik (Gambar 2).

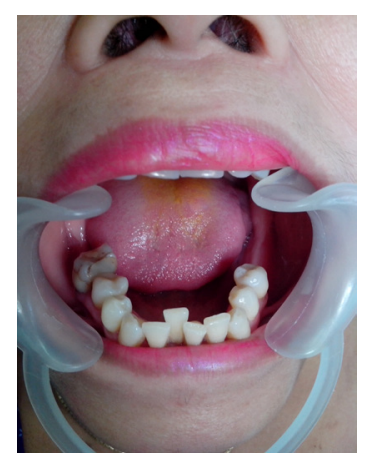

(A)

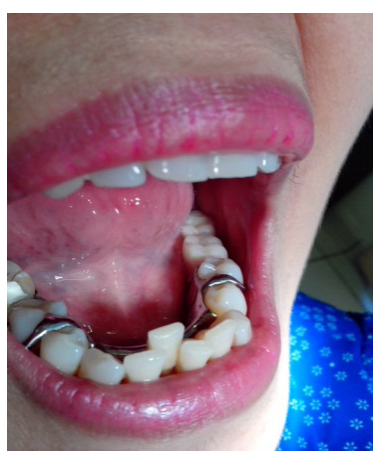

(B)
Gambar 1. (A) Rahang bawah tanpa GTS kerangka logam; (B) Rahang bawah dengan GTS kerangka logam

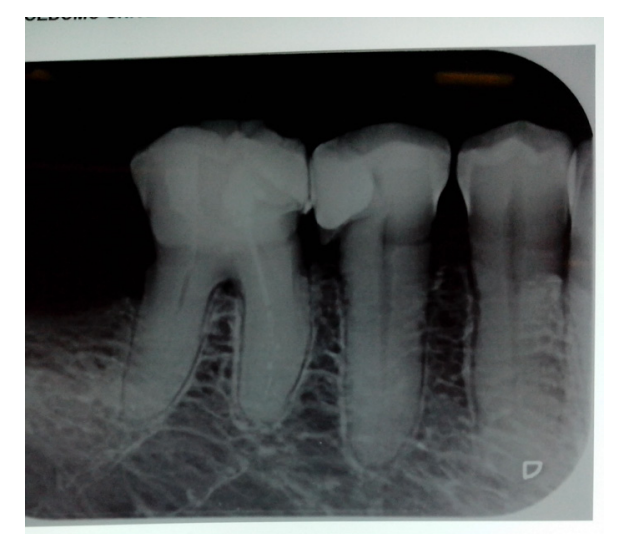

Gambar 2. Gigi 46 pasca perawatan endodontic

Berdasarkan kondisi pasien tersebut dipilih gigi tiruan lepasan dengan retainer kaitan presisi pada rahang bawah yang diharapkan membantu mengatasi keluhan pasien. Penataksanaan kasus, dilakukan perawatan pendahuluan pada pasien berupa re-treatment endodontik gigi 46 karena 
bahan pengisi saluran akar pada perawatan sebelumnya tidak mengisi sempurna. Pasien dikontrol tiga minggu kemudian untuk dilakukan pencetakan model studi.

Dalam penatalaksanaan kasus ini, terdapat tahap persiapan dan tahap pembuatan gigi tiruan sebagian lepasan dengan retainer kaitan presisi ekstrakorona. Tahap persiapan meliputi anamnesa dan pemeriksaan klinis ekstra dan intraoral, pemeriksaan penunjang berupa rontgen foto gigi penyangga dan kdaerah gigi yang hilang, pencetakan pendahuluan untuk mendapatkan model diagnostik dengan alginat, pencocokan warna gigi, dan pembuatan desain gigi tiruan. Adapun model diagnostik dan pencocokan warna gigi seperti gambar berikut:

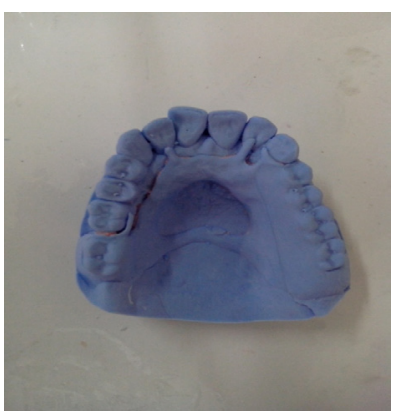

(A)

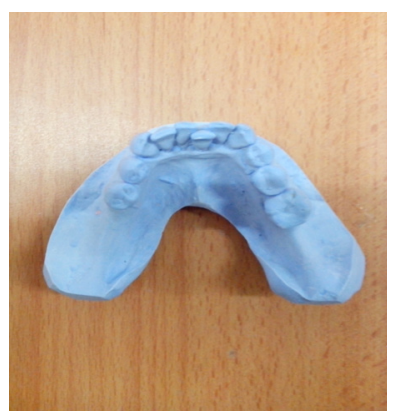

(B)
Gambar 3. (A) Model studi RA; (B) Model studi RB

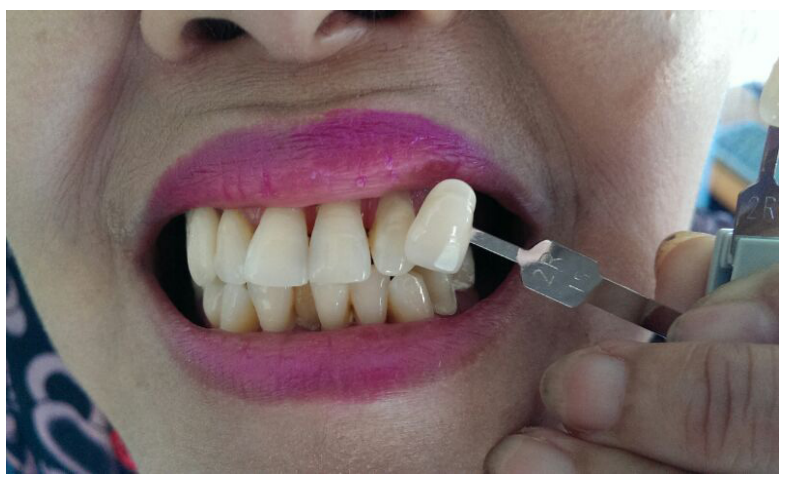

Gambar 4. Pencocokan warna gigi

Tahap pembuatan sendiri terdiri dari beberapa tahap, meliputi preparasi gigi penyangg a berupa mahkota penuh (full crown) pada gigi 34, 35 dan 45,46 . Setelah gigi penyangga selesai di preparasi, kemudian dilakukan pencetakan model kerja dengan polyvinyl siloxane (PVS) menggunakan stock tray no 2. Cetakan diisi dengan glass stone untuk model kerja sebanyak 2 kali. Cetakan I untuk dikirim ke laboratorium, cetakan II untuk persiapan pembuatan mahkota sementara. Adapun tahapan preparasi dan hasil model kerja seperti gambar di bawah:

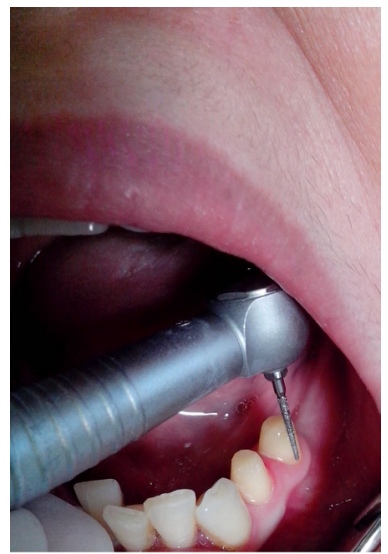

(A)

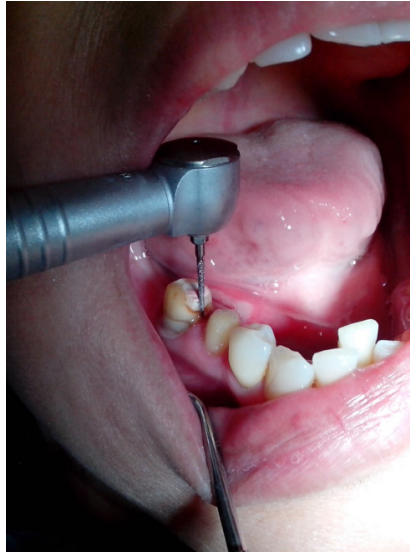

(B)
Gambar 5. (A) Preparasi gigi 34 dan 35; (B) Preparasi gigi 45 dan 46

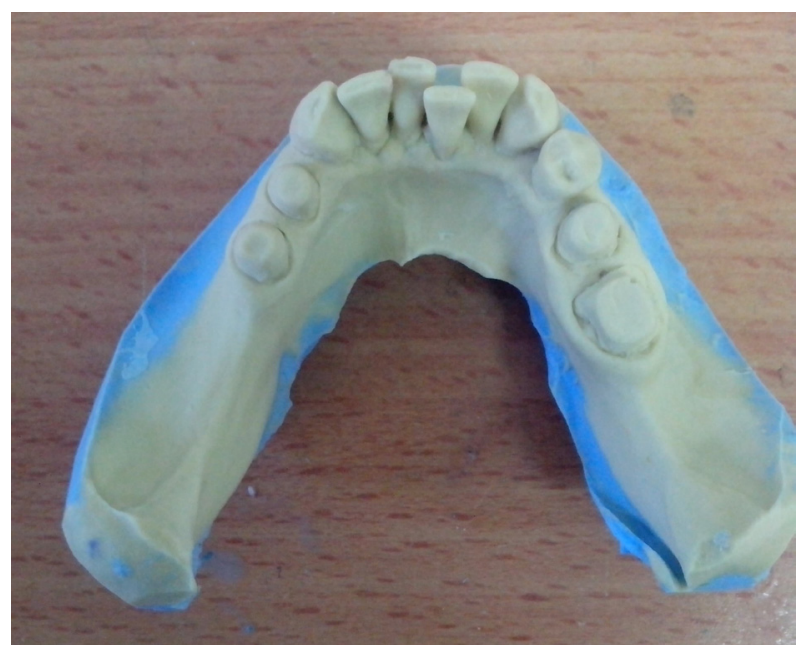

Gambar 6. Model kerja

Tahap berikutnya adalah pembuatan mahkota sementara untuk gigi 34, 35, 45, 46 yang telah dipreparasi. Mahkota sementara berguna untuk melindungi vitalitas gigi penyangga pasien. Pembuatan mahkota sementara dilakukan secara direct menggunakan protemp 3 garant dari 3M. Mahkota sementara kemudian dipasang pada gigi pasien menggunakan freegenol. Adapun hasil mahkota sementara seperti gambar berikut: 


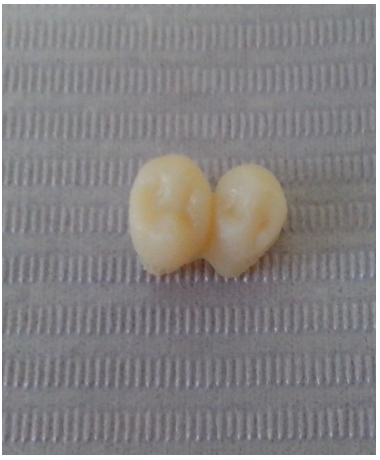

(A)

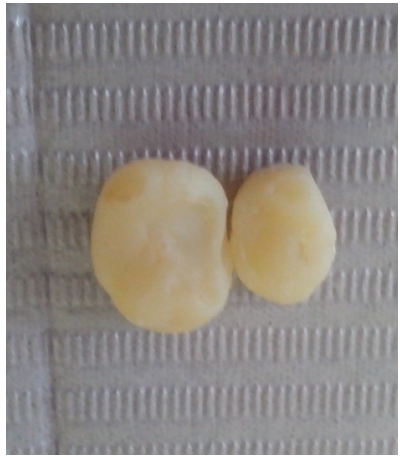

(B)
Gambar 7. (A) Mahkota sementara gigi 34, 35; (B) Mahkota sementara gigi 45,46

Model kerja yang telah didapat kemudian dikirim ke lab untuk dilakukan pembuatan metal coping beserta male. Setelah prosesing lab selesai dilakukan try in metal coping beserta male pada gigi 34, 35 dan 45, 46 untuk mengetahui kerapatan tepi coping dengan finishing line preparasi serta untuk mengetahui jarak interoklusal dengan gigi antagonisnya.
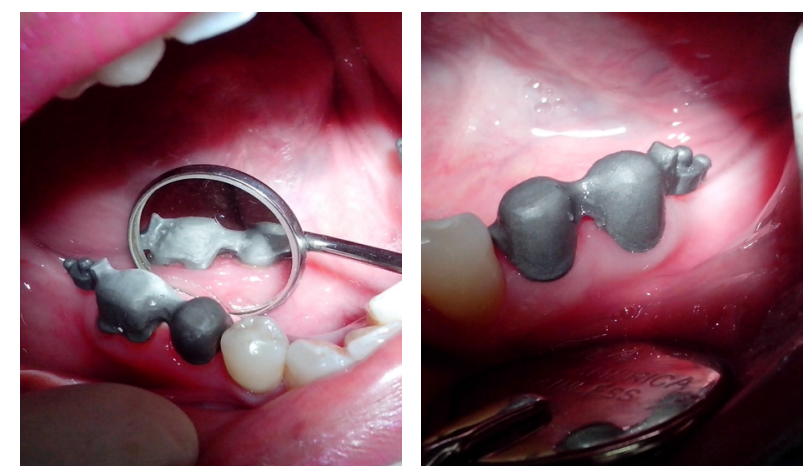

Gambar 8. Try in metal coping kanan dan kiri.

Bersamaan dengan try in metal coping dilakukan pencatatan hubungan rahang atas dan rahang bawah dengan posisi metal coping beserta male masih terpasang di gigi 34, 35, 45, dan 46 . Pencatatan hubungan rahang atas dan bawah dilakukan dengan menggigitkan putty pada regio kanan dan kiri mulut pasien. Hal ini dilakukan untuk mendapatkan posisi oklusi sentris pasien untuk kemudian dicocokan pada model kerja. Setelah oklusi sentris didapat, model kerja beserta coping dikirm kembali ke lab untuk prosesing akhir
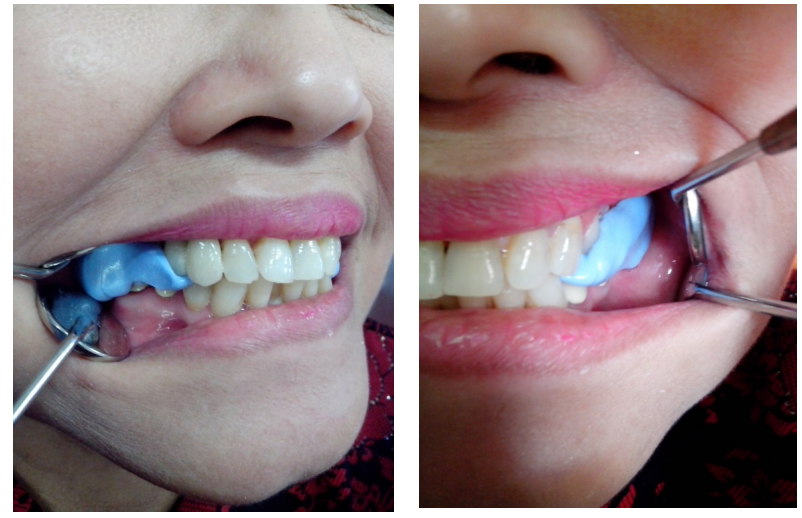

Gambar 9. Pencatatan hubungan RA-RB

Insersi gigi tiruan sebagian lepasan dengan retainer kaitan presisi ekstrakorona RB dilakukan setelah prosesing lab selesai. Pemasangan gigi tiruan dimulai dengan memasang mahkota gigi $34,35,45$, dan 46 yang terdapat bagian male dari kaitan presisi ekstrakorona, masing-masing di distal gigi 35 dan 46 menggunakan luting cement, kemudian dilakukan pengecekan oklusi. Gigi tiruan lepasan yang memiliki bagian female dari kaitan presisi ekstrakorona dipasang kemudian sesuai dengan posisi kaitan male, kemudian dilakukan pengecekan oklusi dan stabilisasi.
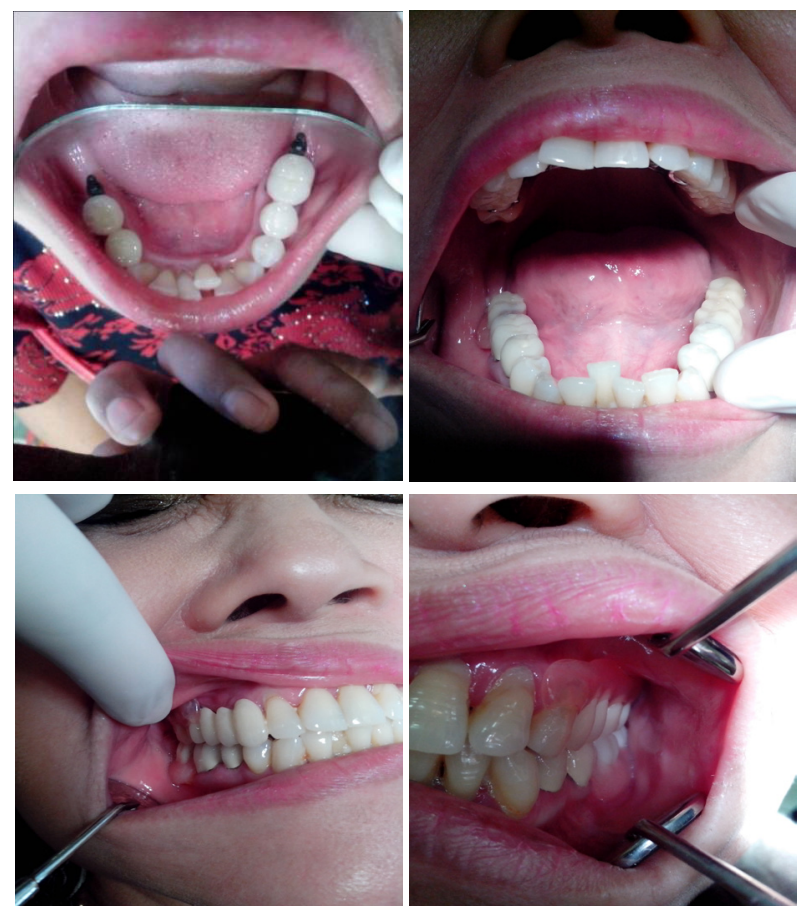

Gambar 10. Insersi GTSL dengan retainer kaitan presisi ekstrakorona 
Kontrol pada pasien dapat dilakukan setelah satu minggu pemakaian untuk mengetahui ada tidaknya keluhan pasien setelah menggunakan gigi tiruan dengan kaitan presisi.

\section{PEMBAHASAN}

Dalam pembuatan gigi tiruan sebagian lepasan, retensi dan stabilisasi merupakan faktor yang harus diperhatikan karena faktor ini akan memberikan hasil yang maksimum. Keberhasilan pembuatan suatu gigi tiruan sebagian lepasan juga akan lebih berhasil bila dapat meningkatkan kenyamanan pasien saat memakai gigi tiruan. Pada pembuatan gigi tiruan sebagian lepasan konvensional seringkali ditemui ketidaknyamanan penggunaan cengkram yang terlihat saat tersenyum, tidak pas, mengurangi kenyamanan fungsi bicara dan pengunyahan akibat desain yang kurang tepat. ${ }^{5}$ Dengan adanya kekurangan pada gigi tiruan sebagian lepasan konvensional, maka penggunaan kaitan presisi dapat menjadi salah satu pilihan perawatan.

Penggunaan kaitan presisi sebagai alat retensi gigi tiruan sebagian lepasan terdiri dari beberapa macam kaitan berdasarkan letak dan fungsinya. Kaitan presisi berdasarkan letaknya terdiri dari kaitan presisi ekstrakorona, intrakorona, radikular stud, dan bar. Kaitan presisi berdasarkan fungsinya terdiri dari kaitan rigid dan passive. ${ }^{6}$

Pada kasus ini, gigi tiruan sebagian lepasan dengan retainer kaitan presisi dibuat ekstrakorona untuk rahang bawah bilateral free end. Pemilihan kaitan ekstrakorona ini bertujuan untuk mendapatkan gigi tiruan yang lebih baik dari segi retensi, stabilisasi, estetis dan kenyamanan. Pemilhan ini juga didasari pada pengurangan gigi pegangan yang tidak terlalu banyak sehingga kontur mahkota gigi pegangan tidak banyak berubah dan vitalitas gigi pegangan tetap terjaga, selain itu kaitan ekstrakorona juga mudah untuk dilepas pasang oleh pasien sendiri.

Pembuatan gigi tiruan sebagian lepasan dengan retainer kaitan presisi ekstrakorona dapat dibuat dengan desain bilateral ataupun unilateral. Gupta, dkk., ${ }^{7}$ menggunakan gigi tiruan sebagian lepasan kerangka logam dengan retainer kaitan presisi ekstrakorona desain bilateral pada kasus kennedy kelas I rahang atas. Jain, dkk., ${ }^{5}$ juga menggunakan kerangka logam sebagai konektor mayor pada kasus kennedy kelas II modifikasi 1 rahang bawah dengan retainer kaitan presisi ekstrakorona.

Desain gigi tiruan sebagian yang dipilih pada kasus ini dibuat desain unilateral tiap sisi. Pemisahan ini didasari pada pengalaman pasien yang merasa kurang nyaman dengan lingual bar yang melintang di depan lidah. Dengan pemisahan ini, kenyamanan pasien dalam menggunakan gigi tiruan dapat meningkat.

Pemeriksaan objektif dan subjektif perlu dilakukan pada pasien satu minggu setelah insersi untuk melihat ada tidaknya keluhan. Pada pemeriksaan objektif, tidak terdapat radang pada gingiva dibawah kaitan, maupun penumpukan sisa makanan. Pasien juga merasa lebih nyaman setelah menggunakan gigi tiruan dengan retainer kaitan presisi ekstrakorona karena tidak merasakan adanya benda asing yang melintang di depan lidah. Pasien diinstruksikan untuk tetap menjaga kebersihan rongga mulutnya dan kontrol periodik setiap enam bulan sekali bila perlu.

Gigi tiruan sebagian lepasan rahang bawah dengan retainer kaitan presisi ekstrakorona merupakan suatu pilihan perawatan dalam pembuatan gigi tiruan lepasan. Penggunaan kaitan presisi dapat dilakukan pada kasus ujung bebas dan dapat dibuat desain unilateral tiap sisi. Pemakaian kaitan selain dapat menghasilkan retensi dan stabilisasi yang baik, juga dapat membantu meningkatkan segi kenyamanan penggunaan gigi tiruan pada pasien sehingga dapat meningkatkan kepercayaan diri pasien dalam berinteraksi sosial. Hal ini senada dengan pernyataan Jain $^{5}$, dkk yang menyebutkan bahwa kaitan presisi memiliki kelebihan luar biasa sebagai suatu gigi tiruan sebagian lepasan karena dapat meningkatkan estetis, kenyamanan, dan dapat menjadi pilihan bagi pasien yang tidak menghendaki dilakukan pemasangan implant namun menginginkan retensi yang cukup kuat. 


\section{KESIMPULAN}

Pembuatan gigi tiruan sebagian lepasan rahang bawah dengan retainer kaitan presisi ekstrakorona desain unilateral tiap sisi pada kasus Kennedy klas I dapat menjadi pilihan untuk meningkatkan kenyamanan pasien dalam pemakaian gigi tiruan lepasan.

\section{DAFTAR PUSTAKA}

1. Battistuzzi PGFCM, Kayser AF, Keltjens HMAM, Plasmans PJJM. Gigi tiruan sebagian: titik tolak pada diagnosa dan perawatan dari gigi-geligi yang rusak. Alih bahasa. Al Kosasih, AR Kosasih. Jakarta.Widya Medika. 1996; $164-190$

2. Gunadi H A,. Buku Ajar ilmu geligi tiruan sebagian lepasan Jilid I.. cetakan II. Jakarta.Hipokrates. 1995;14

3. Watt DM, Mac Gregor AR. Designing partial dentures. Alih bahasa. Yuwono L.Hipokrates. Jakarta, 1984; 90-109
4. Jayasree K, Bharathi M, Nag VD, Vinod B. Precision attachment: retained. Overdenture J Indian. Prosthodont Soc. 2012; 12 (1) : 5962

5. Jain AR, Philip JM, Ariga P. Attachmentretained unilateral distal extension (kennedy's class ii moddification. Cast Partial DentureJpjournals. 2012; 2 (3): 101-107

6. Khare A, Makkar S, Roshna. T Full Mouth rehabilitation with fixed and removal prosthesis using extracoronal attachments: a clinical report. Journal of Scientific Research. 2011; 4(2): 47-52

7. Gupta N, Bhasin A, Gupta P, Malhotra P. Case report: combined prosthesis with extracoronal castable precision attachments In: Case reports in dentistry india. Hindawi Publishing Corporation. 2013; 10(13): 1-4 